Revue d'études américaines. American Studies Journal

$2 \mid 2017$

(Hi)stories of American Women: Writings and Rewritings / Call and Answer: Dialoguing the American West in France

\title{
Negotiating, Subverting, Reconfiguring Borders in the English-Speaking World
}

Université de Strasbourg, October 6-7, 2018

\section{Pierre Le Duff and Cezara Bobeica}

\section{(2) OpenEdition}

\section{Electronic version}

URL: https://journals.openedition.org/transatlantica/10290

DOI: 10.4000/transatlantica.10290

ISSN: $1765-2766$

\section{Publisher}

Association française d'Etudes Américaines (AFEA)

\section{Electronic reference}

Pierre Le Duff and Cezara Bobeica, "Negotiating, Subverting, Reconfiguring Borders in the EnglishSpeaking World", Transatlantica [Online], 2 | 2017, Online since 27 May 2019, connection on 02 February 2023. URL: http://journals.openedition.org/transatlantica/10290 ; DOI: https://doi.org/ 10.4000/transatlantica.10290

This text was automatically generated on 2 February 2023.

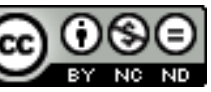

Creative Commons - Attribution-NonCommercial-NoDerivatives 4.0 International - CC BY-NC-ND 4.0 https://creativecommons.org/licenses/by-nc-nd/4.0/ 


\title{
Negotiating, Subverting, Reconfiguring Borders in the English-Speaking World
}

Université de Strasbourg, October 6-7, 2018

\author{
Pierre Le Duff and Cezara Bobeica
}

1 "There are no clear borders, only merging invisible to the sight," wrote the Serbian poet Dejan Stojanović in his 1993 collection Circling: 1978-1987. Borders, whether clear or not, whether material or conceptual, nonetheless shape, constrain, structure, and divide space, time, people, and thought. Borders are ambivalent by their very nature, as they are both points of separation and points of contact. To borrow a Wildean phrase, they are "rarely pure and never simple," and therefore serve as an extraordinarily fruitful object of scholarly attention.

2 The interdisciplinary conference "Negotiating, Subverting, Reconfiguring Borders in the English-Speaking World," held in Strasbourg on the $6^{\text {th }}$ and $7^{\text {th }}$ of October 2018, and hosted by SEARCH (Savoirs dans l'Espace Anglophone : Représentations, Culture, Histoire), one of the English Department's research teams at the Université de Strasbourg, truly testified to the notion's range of implications. Via 8 panels and 3 keynote speeches from experts in fields as diverse as literature, cultural studies, art history, architecture, photography, history, geopolitics, journalism, gender studies, and science fiction, the conference questioned numerous crucial aspects of a concept that is as complex as ubiquitous. The United States held a major place in the subjects discussed, which bears witness to the particular importance of concepts such as "the border" or "the frontier" in the American episteme, as well as to the specific issues they have raised, and continue to raise in the US.

3 Geopolitical borders, firstly, lie at the heart of concerns and debates that, ironically, almost systematically cross disciplinary limits and reach deep into adjacent areas of discourse, including culture, language, economic and social questions, and sovereignty. In his talk "Warped Mirrors: Shifting Representations and Asymmetrical Constructs on the Border(s) of the American Southwest," Jeffrey Swartwood, explored the manner in 
which cultural communities on both sides of the southern border(s) of the United States were integrated into the American historical narrative, most notably through the example of the different communities that inhabited the San Diego area during and after the Mexican-American war (1846-1848). Swartwood argued that these communities resist neat categorisation as either American or Mexican, and that the particular geographic and cultural context of $19^{\text {th }}$-century San Diego allowed for much more racial and cultural diversity than any other area in either country. This challenges the notion that the Mexican-American war was a conflict between two unified nation states, and provides valuable data to explain the construction of cultural identities.

4 In her talk "We Don't Cross the Border, It's the Border That Crosses Us," Léna RémyKovach explored the colonial effort to map an unknown geographic entity according to Eurocentric viewpoints and concerns, and its impact on two Native communities mainly, the Akwesasne Kanien'kehá:ka (Mohawk), and the Anishinaabe (Ojibwe) of the Great Lakes region. As Rémy-Kovach puts it, "this Western cartography system introduced a new geographical imaginary which ignored indigenous ways of knowing and recording space." Instead, borders also reflected the Anglo-French conflict and the American Revolution, in which several indigenous communities participated as allies to one party or the other, and constituted an extremely efficient tool for clearing land and attributing it to settlers. Furthermore, some of these borders outlasted these historical episodes. Even today, Rémy-Kovach showed, the movement of Native American communities from one country to another is anything but unrestricted, and many communities are still the victims of various levels of discrimination.

5 In their presentation titled "Transgressing and rethinking borders in Rapid City, SD and on the Great Sioux Reservation," Céline Planchou and Sandrine Baudry focused on the particular case of a town in South Dakota, and on the way its founding and expansion affected the pre-existing local Sioux population. Rapid City, which originated as an illegal settlement on Lakota land in the late $19^{\text {th }}$ century, quickly became a contested space, among other reasons because the nearby Black Hills were ceremonial places of great spiritual value to the Lakota communities. Planchou and Baudry argued that change has been extremely slow, and that racism and discrimination still exist in Rapid City in the $21^{\text {st }}$ century. Even within this theoretically unified urban space, a clear border still separates the wealthy downtown districts and those mainly inhabited by Native American minorities. Materialised by a railroad track, it stands at odds with the spiritual and cultural value that Native communities attach to the land, and even negates it.

6 In his presentation titled "'He came a long way to see his white brothers the Cherokees and the Creeks' : Les Indiens relocalisés à l'ouest du Mississippi comme settlerscolonisateurs des Plaines et agents de la 'civilisation' américaine sur une nouvelle frontière 'entre autochtones' (1817-1853)?," Augustin Habran, argued that several of the so-called "Civilised Nations" among the Native American population in fact participated in the creation of an American identity in the West, largely as a coping mechanism in the context of dispossession and westward expansion. Through a form of cultural mimesis, some Native American tribes managed to reconfigure space and borders to their advantage, a strategy that would allow them to become ambassadors of the new dominant cultural identity while safeguarding aspects of their own Native culture. Habran's paper called for a rethinking of the mapping of the early United 
States, and for a more nuanced approach to the traditionally dichotomous views on the ethnic and cultural borders between Native Americans and white settlers.

Both geographical and cultural borders were the topic of another presentation given by Professor Mohamed Yazid Bendjeddou, titled "Representations of the Frontier in Mary Rowlandson's A Narrative of the Captivity and Restoration of Mrs. Mary Rowlandson." The famous autobiographical account of a Puritan woman held captive by a troop of Native American raiders in the late $17^{\text {th }}$ century constitutes first-hand material to study the notion of the frontier, both in the eyes of the prisoner and in the minds of her captors. Professor Bendjeddou first examined the "physical" manifestation of the border, which held crucial importance both for the Natives and the settlers: the former saw it as a vital necessity to maintain it, the latter as the frontier to be crossed to fulfil their "Manifest Destiny" of westward conquest. But Rowlandson's narrative, he further showed, also yields valuable information concerning the way in which the Natives were viewed in white, and especially Puritan, communities, and the way in which the notion of the Frontier was constructed on both sides.

8 Another striking example was presented by Scullion in her talk “"There are no perfect boundaries, no natural borders except winding rivers': Maps, Landscape and Decolonial Resistance in the work of Louise Erdrich," a contemporary Native American writer, particularly in her 1988 novel Tracks. Scullion showed how Erdrich's narrative makes tangible the inescapable tension between Native Americans' concept of land and space, and the latter's systematic and arbitrary remapping by white settlers. This is notably achieved through an ekphrastic description of a map in the novel, on which the rapid encroachment of colonial powers into Native American land is visually overwhelming and oppressive.

9 Border reconfiguration is, of course, a wide-ranging question outside the United States as well. The consequences of Brexit were explored from several perspectives too: that of Gibraltar in the presentation "'Between a Rock and a Hard Place': a short (and very personal) history of the Gibraltar border" by G.M. Sanchez; that of borders dividing the British Isles in the presentation "Brexit or the reconfiguration of borders" by Professor Christian Auer; and that of the Irish border in the talk "Visualising (Northern) Irish Border(s): The Contested Imagined Geographies of Murals from the Conflict to Brexit" by Caroline Lehni.

10 A more uplifting talk titled "Frontiers of Peace" was given by Valerio Vincenzo, in which he showed that today, frontiers in Europe are far closer to being points of contact than lines of separation.

11 The way in which humans perceive and represent borders is therefore as relevant as that in which borders materialise. In the area of border representation in literature and the arts, the United States was, once again, well represented at the conference.

12 As a trained surveyor, Henry David Thoreau certainly understood the implications of territory mapping, but, as Julien Nègre demonstrated in his paper "Writing without borders? Thoreau's remapping of borders through and within language," the American author saw a profound connection between physical and linguistic borders, and sought to explore them, sometimes simultaneously, in his writings. Thoreau's stance was deeply subversive; in Nègre's words, "most of his excursions into the border topos are challenges to the validity of his contemporaries' take on borders." Nègre used three pictorial documents as a starting point: a detail from a map of the state of Maine used by Thoreau himself during his excursions, a map of a swamp, and the outline of a leaf, 
both drawn by Thoreau himself. These three documents, when examined in the light of Thoreau's writings, could serve as a map towards the most fundamental issues involved in cartography, both geographical and conceptual, such as the limits of perception, the tension between representations and reality, as well as the borders within language and meaning. In Nègre's words again, Thoreau chooses to "inhabit the border," so as to understand and, ultimately, transcend and subvert it.

Borders and limitations are a recurrent subject in literature in general, but their manifestation and treatment vary greatly from one author to the next.

Cartography, however, is not the only way in which borders can materialise. As Frédérique Spill demonstrated in her talk “'One man's tenuous hold on the earth': the metaphor of barbed wire in Ron Rash's writing," barbed wire, a comparatively rudimentary way of enclosing space, can nonetheless serve as a powerful image to define and subvert the very notion of a border. Particularly through Rash's 2004 novel One Foot in Eden, Spill showed how barbed wire could shift from a threatening limit to an invitation to trespassing, and could even become a tool of redemption while serving as an allegorical, Christ-like attribute.

In her presentation titled "Undermining borders in The Girl in the Tangerine Scarf," a novel by Arab American writer Mohja Kahf, Sara Arami explored the way in which less physical and more ideological borders are used to create and maintain cultural identities among Arab communities living in the United States, and how all borders and frontiers are unsettled once the geographical limit is crossed. Arami showed that, despite all efforts of communities to enforce a dichotomous worldview in which each is clearly differentiated from the other, borders are porous, and cultures can end up overlapping. The novel, Arami argued, calls for counternarratives engaging in what she called "cartographic map-breaking," to subvert fixed and defined borders between cultures and communities.

other borders, and their transgression, may however raise far more troubling ontological and epistemological questions concerning the human nature. Stefania Iliescu explored this difficult subject in her talk titled "'There are no horizons here': L'effritement des frontières dans Zero $K$ de Don DeLillo." In this novel, wealthy and powerful individuals gather in an enclosed space called the "Convergence," where the limits imposed on humans by nature, first and foremost among them death, are to be transcended and nullified. Iliescu argued that, in DeLillo's work, such a project comes at a price, namely abandoning all past frameworks for thought and speech. The novel thus questions contemporary goals of crossing the final border towards "post-humanity," as well as the consequences that such a breakthrough would entail vis-à-vis the features still deemed most essential to humanity.

Naturally writers from other countries have also pondered the notion of borders. The liminal space between borders, as well as the act of crossing the border, were studied from a literary perspective in the talks "James Joyce's Rome as Inter-Imperial Zone" by Sara Ceroni, "Crossing borders in imperial India: a geocritical study of subversive transgressions in R. Kipling's Kim and E.M. Forster's A Passage to India" by Amandine Guyot, and 'Everything Outside the Border is Wilderness': Border-Crossings in Sarah Hall's The Wolf Border" by Julia Ditter. In his talk “'Indigeneity', 'Statism' and 'Federal Character': The manufacture of Inter-Communal borders in the Federal Republic of Nigeria," Joseph Egwurube provided new insights into the question of Nigerian 
federalism, and yet another particular situation was discussed by Pascal Zinck in his presentation "Lines of Control: Borders Without a Country."

Two presentations focused more particularly on geographical, ethnical, and cultural borders in Caribbean texts: “'Dark strangers crossing the nation's threshold': Reading Literal and Metaphorical borders in George Lamming and Samuel Selvon" by Silvia Gerlsbeck and "'Whey Mi Belang': Borders of Class, Race and Gender in Reggae Lyrics and Afro-Caribbean Oral Texts" by David Bousquet. These presentations offered new perspectives on the question of emigration from the Caribbean towards the United States. Lastly, in his talk "Akwaeke Emezi's Freshwater (2018): or, "Ogbanjehood" as Liminal State," Cédric Courtois explored the question of the liminal space between the self and the other in the context of Nigerian culture.

Two further talks reminded us that borders can exist even within seemingly unified spaces and communities, and that their transgression can be a long and arduous process.

In her paper 'De 'L'Ange du foyer' à la suffragette: comment la 'nouvelle femme' a franchi la frontière entre sphère privée et sphère publique, Grande-Bretagne, 1854-1918," Laurence Cristina presented a historical account of the slow but irresistible progress of women's rights. As her-very original-starting point to investigate the significant changes that occurred during that period, she chose the date of publication of the poem "The Angel in the House" by Coventry Patmore.

Shirley Doulière focused on a different type of woman altogether in her talk "Victorian female explorers navigate the borders of femininity." While women such as Mary Seacole, Isabella Bird, Mary Kingsley, and Gertrude Bell chose to pursue undertakings that were usually male territory, they still deliberately maintained a conventionally female image, thus constituting fascinating cases of navigating the border between genders. That similar questions still arise today, in the United States and elsewhere, is a testimony to their ubiquity and their importance in contemporary societies.

Two papers studied forests as particular liminal spaces. In her keynote address "Frontières mouvantes: les forêts anglaises entre institutions et imaginaires," Professor Sylvie Nail covered the popular movements that arose in Britain from 2010 on after the government announced its intention to privatise large parts of the forests previously administered by the Forestry Commission. This movement highlighted the deeply ingrained cultural attachment of British people to the woodlands across cultural borders, and the various social, artistic and environmental measures that were taken to keep the forests public and open to all.

In her talk "The Past in the Present: The Black Forest in Victorian Periodicals as cultural border experience," Stefanie Lethbridge examined English accounts of the Black Forest, which constantly oscillated between the pragmatic tone of tourist guides and the mythical narratives that shaped the image of the forest as backdrop to fairy tales and horror stories, thus blurring the borders between the two.

Though focused on the UK and not on the US, both these presentations raised questions that would be just as relevant to American studies. The close cultural rapport to nature, the idea of unexplored territory as the setting of stories bordering on the mythical, and liminal spaces between the wilderness and civilisation still fascinate artists and scholars alike, and should remain a rich source of inspiration on both sides of the Atlantic for years to come. 

"claustrophilia" in various science-fiction films and one television series in his presentation "Between Final Frontier and Border Control: The Cartographic Imagination of Science Fiction." He showed how the fear of imminent nuclear war and the first steps towards the conquest of space shaped American science fiction narratives from the 1950s on, as people were simultaneously-and paradoxically-drawn to the alleged safety of enclosed bunkers beneath the earth and to the infinity of space. His comparative study of the milestone films Forbidden Planet (1956), 2001 A Space Odyssey (1968), and Total Recall (1990), as well as of the basic principles behind the Star Trek narrative showed how science fiction envisions the notions of space, time, and frontier at different times, and how it oscillates between utopian and dystopian views of the same.

Finally, in his presentation "II think the major issue in art is what are the boundaries'Allan Kaprow, Robert Smithson and the Art of Their Time," Professor Philip Ursprung presented several works of art produced in the late $20^{\text {th }}$ and early $21^{\text {st }}$ centuries, most notably by American artists Allan Kaprow and Robert Smithson, in which ideas such as the border, space, contingency, but also art itself, were raised in a very original fashion. The piece "Sweet Wall" (1970), which required beholders to join in to build a wall out of bricks sealed with bread and jam, mirrored the iron curtain and the Berlin wall while subverting the very idea of a limit, as it enclosed nothing and was free standing in the middle of an open area. This, and other pieces including Smithson's "Partially Buried Shed" and Kaprow's "Fluids," promote art as a mode of expression that, in Ursprung's words, "should interact with reality and society" and help us question our views on all types of borders and limitations.

\section{INDEX}

Subjects: Actualité de la recherche

\section{AUTHORS}

\section{PIERRE LE DUFF}

Université de Strasbourg

\section{CEZARA BOBEICA}

Université de Strasbourg 